\section{Niveis de Testosterona Sérica Elevados em Mulheres: Necessidade de Confirmação com Diferentes Metodologias}

Sr. Editor,

$\mathrm{V}$ ALORES FALSAMENTE ELEVADOS de hormônios esteróides, obtidos com o emprego de imunoensaios diretos (sem extração), é um assunto de importância e tem chamado atenção devido às suas potenciais implicações (1). A dosagem de testosterona sérica é método de rotina requisitado em diversas condições clínicas, em homens e mulheres. A demanda crescente motivou os laboratórios clínicos a adotar métodos automáticos não isotópicos e diretos em substituição ao clássico radioimunoensaio pósextração. No caso das amostras de homens adultos, as metodologias apresentam alta correlação, mas, no caso de amostras femininas, existe um debate importante sobre a validade dos resultados obtidos com os ensaios diretos, sem extração $(2,3)$. Nós recentemente adotamos em nossa rotina um ensaio eletroquimioluminométrico (ECLIA) (4) desenvolvido para uso no aparelho automático Modular E-170 (Roche). Com base em 4872 amostras de rotina, coletadas ao longo de dois meses, selecionamos 80 amostras provenientes de mulheres adultas que apresentavam valores acima de $100 \mathrm{ng} / \mathrm{dL}(3,47 \mathrm{nmol} / \mathrm{L})$. Este nível foi selecionado por considerarmos que amostras com valores acima de $100 \mathrm{ng} / \mathrm{dL}$ são inquestionavelmente elevadas. Essas amostras foram, então, redosadas empregando-se um radioimunoensaio (RIE) clássico que inclui extração prévia, e um método imunoquimioluminométrico (ILMA) automatizado, direto, adaptado para o equipamento ACS-180 (Bayer). Empregando-se o teste de Wilcoxon, observamos que os resultados obtidos com o ECLIA foram significativamente mais elevados que os obtidos com o RIE e com o ILMA $(\mathrm{P}<0,0001)$, com medianas de $132,5,107,0$ e $98,0 \mathrm{ng} / \mathrm{dL}$, respectivamente. Os resultados obtidos com o RIE e com o ILMA não foram estatisticamente diferentes $(\mathrm{P}=0,2576)$. A correlação de Spearman ( $\mathrm{rs})$ calculada entre os resultados do ECLIA e RIE foi de 0,4012, entre o ECLIA e o ILMA 0,3861, e entre o RIE e o ILMA 0,9145. Uma análise mais detalhada dos resultados mostrou que em $65 \%$ (50/80), os valores obtidos pelos três métodos eram muito semelhantes entre si, sendo as diferenças observadas devidas às 30 amostras restantes, onde os valores obtidos pelo ECLIA eram significativamente mais elevados. Não tivemos oportunidade de validar os resultados usando um método de referência como GC-MS (5), mas a alta correlação obtida entre os resultados do RIE e do ILMA sugere uma superestimação pelo ECLIA nessas 30 amostras (cujos resultados foram abaixo de $100 \mathrm{ng} / \mathrm{dL}$ nos outros dois métodos). Nossos dados chamam a atenção para o problema de possíveis valores falsamente elevados obtidos pelo emprego de métodos diretos para a medida de testosterona sérica, possivelmente devidos a interferentes inespecíficos. Estes achados sugerem dependência metodológica e devem ser levados em consideração quando da escolha de metodologia ou da análise de resultados de pacientes do sexo feminino. Chamam a atenção, ainda, para o fato de que metodologias mais específicas devem ser desenvolvidas para que este tipo

\section{cartas ao editor}

\author{
José Gilberto H.Vieiva \\ Cláudia Maria Ferver \\ Maria Teresa Ghiringhello \\ Odete Nakamura \\ Omar Magid Hauache
}

Setor de Imunoensaios, Laboratório Fleury, São Paulo, SP 
de dosagem hormonal possa ter a validade que a investigação clínica necessita.

\section{REFERÊNCIAS}

1. Vieira JGH, Tachibana TT, Noguti KO, Ferrer CM, Maciel RMB. Valores falsamente elevados em ensaios diretos para a medida de hormônios esteróides no soro. J Bras Patol 1999;35:71-4.

2. Herold DA, Fitzgerald RL. Immunoassays for testosterone in women: better than a guess? Clin Chem 2003;49:1250-1.

3. Taieb J, Mathian B, Millot F, Patricot M-C, Mathieu E, Queyrel $N$, et al. Testosterone measured by 10 immunoassays and isotope-dilution gas chromatography-mass spectrometry in sera from 116 men, women, and children. Clin Chem 2003;49:1381-95.
4. Sánchez-Carbayo $M$, Mauri M, Alfayate $R$, Miralles $C$, Soria F. Elecsys testosterone assay evaluated. Clin Chem 1998;44:1744-6.

5. Fitzgerald RL, Herold DA. Serum testosterone: immunoassay compared with negative chemical ionization gas chromatography-mass spectrometry. Clin Chem 1996;42:749-55.

\section{Endereço para correspondência:}

José Gilberto H. Vieira

Setor de Imunoensaios

Laboratório Fleury

Av. General Waldomiro de Lima 508

04344-070 São Paulo, SP

e-mail: jose.vieira@fleury.com.br 